\title{
Prevalence of Carcinoma in Celiac Patients
}

\author{
Taufner $\mathrm{GH}^{1}$ and Afranio Cogo Destefani* \\ 1,2Biomedic, Master student in Biotechnology from the Federal University of Espírito Santo Brasil \\ ${ }^{*}$ Pharmacist Biochemist, PhD Student in Biotechnology from the Federal University of Espírito Santo (UFES), Brasil
}

Submission: February 14, 2017; Published: March 06, 2017

"Correspondence Address: Destefani AC, Pharmacist Biochemist, PhD Student in Biotechnology from the Federal University of Espírito Santo (UFES), Av. Marechal Campos, 1468 - Maruípe, Vitória, ES, Brasil, CEP, Tel: 29043-900; Email: afraniocd@gmail.com

\begin{abstract}
Celiac disease (CD) is an autoimmune disease that affects genetically predisposed individuals. The prevalence among people of European descent is about 1\%, and it is estimated that in Brazil about 300 thousand people have the disease. The celiac is subject to several mild complications, such as diarrhea, flatulence and abdominal distension. However, those who are not diagnosed or who do not adhere to the gluten-free diet are prone to develop malignant complications such as cancer. Celiacs are 1.29 times more likely to develop intestinal and extra-intestinal neoplasms than healthy people and are more likely to develop non-Hodgkin's lymphoma and small bowel adenocarcinoma.
\end{abstract}

Keywords: Celiac disease; carcinoma; prevalence; complications

Abbreviations: CD: Celiac Disease; NHL: Non-Hodgkin's; LPD: Lympho-Proliferative Disorders

\section{Introduction}

Celiac disease (CD) is an autoimmune disease that affects genetically predisposed individuals through the ingestion of foods containing gluten proteins, the main compound of wheat, oats, rye, barley and malt [1-3]. It is characterized by changes in the small intestine of the carriers, such as the decrease of the intestinal villi and, consequently, of the area of nutrient absorption $[3,4]$. The prevalence of the disease among people of European descent ranges from 0.3 to $1 \%$ [1,5-7]. In Brazil, official statistical data are unknown, however, it is estimated that 300,000 Brazilians are carriers of the disease [1].

The celiac is subject to several mild complications, such as diarrhea, flatulence and abdominal distension; however, in some cases, there are reports of severe respiratory, neurological, nutritional, obstetric and reproductive complications, in addition to mainly several types of neoplasias that raise mortality rates [8-10]. Patients, especially those not diagnosed or who do not adhere to the gluten-free diet, are likely to develop malignant complications, such as cancer [11], and it has been reported that the main celiac carcinomas are lymphomas and adenocarcinomas [12]. Given the severity of the correlation between carcinoma and celiac disease, this article aims to review the prevalence of major cancers associated with celiac disease.

\section{Types of Carcinoma and Prevalence}

Celiacs are 1.29 times more likely to develop intestinal and extra-intestinal neoplasms than healthy people $[13,14]$. Celiac patients are primarily affected with non-Hodgkin's lymphoma and small bowel adenocarcinoma [14-16], however, there are other types of carcinomas such as oesophagal and oropharyngeal reported but are less frequent, but the consequences are equally severe when untreated [17-19].

Lymphomas are neoplasms characterized by the transformation of any class of lymphocytes into malignant cells. Most of them originate from lymph nodes or ganglia. There are two classes of lymphoma. Hodgkin's disease, characterized by the presence of large cells called Reed-Sternberg, and inflammatory cells. This class represents $12 \%$ of all cases. Unlike the first subtype, non-Hodgkin's (NHL) is much more common, being subdivided into NHL T lymphocytes, which encompass cutaneous $\mathrm{T}$ cells, peripheral $\mathrm{T}$ cells and T-cell lymphoma associated with enteropathy, and NHL B cells encompass lymphoma Diffuse large B-cells, mantle cells, marginal and follicular zone [20].

Although it is less frequent than the subtype that affects B-cells, T-cell lymphoma when associated with the disease is the leading cause of death in patients, and usually, develops in the jejunum, however, it may occur in the ileum and extra intestinal sites, such as liver, brain, chest and bone 21.This type of carcinoma is most prevalent in people close to 60 years of age and the survival rate is relatively low, about $15-20 \%$ of patients survive up to 2 years [20].

In a study by Catassi et al. [21] in a group of 653 patients with lymphoma 6 celiacs $(0.92 \%)$ were identified, of which 3 


\section{Cancer Therapy \& Oncology International Journal}

were B-cell lymphomas and 3 T-cell lymphomas. Most of these cases reported the disease was mainly in the intestine [22]. Leslie et al. [20] studied 1,285 patients with biopsy proven celiac disease during the years 1981 and 2010 and identified 40 cases of lymphoma, of which 33 were non-Hodgkin's lymphomas. Among these identified cases, 16 were characterized as B-cell NHL, another 12 cases were NHL T lymphocytes associated with enteropathy and another 5 were NHL T cells not associated with enteropathy. Patients who developed lymphoproliferative disorders (LPD) were older in the diagnosis of celiac disease $(57.9 \pm 15.5$ vs $42.5 \pm 17.4$ years, $\mathrm{P}<0.0001)$ and more likely to present diarrhea $(60,0 \%$ vs. $39.8 \% \mathrm{P}=0.016)$, abdominal pain $(17.5 \%$ vs. $5.5 \% \mathrm{P}=0.0046)$, and $/$ or weight loss $(12.5 \%$ vs. $4.0 \%$ $\mathrm{P}=0.028)$. Patients with enteropathy-associated T-cell NHL had a shorter mean survival than patients with non-enteropathic T-cell NHL (3.2 versus 15.0 years, $P=0.016$ ) [20].

In addition to lymphomas, there is also a high risk of adenocarcinomas of the oropharynx, oesophagus, pancreatic, hepatobiliary and mainly intestine [2,3,23]. Adenocarcinoma is a malignant neoplasm that occurs in glandular epithelial tissues, which are generally extremely aggressive and difficult to remove surgically, which results in an unfavorable prognosis; however, if removal occurs, the prognosis is better than patients with lymphoma [24-26]. Its incidence under normal conditions is approximately 1 case per 100,000 people, representing about $5 \%$ of all cancers of the gastrointestinal tract [27-29]. Experts suggest that adenocarcinomas associated with celiac disease have arisen through the development of an adenoma for carcinoma $[11,28]$. Although less frequent than lymphomas, Freeman et al. [23] identified in a group of 35 patients with celiac disease reported after 60 years, 10 cases of lymphoma and adenocarcinoma of the small intestine [23]. Howder et al. [16] conducted a study of 395 reported cases of carcinomas in the UK and found celiac disease associated with $39 \%$ of lymphomas in a group of 107 patients and $13 \%$ of small bowel adenocarcinomas in a group of 175 patients [16].

An increased risk of oesophagal and pharyngeal carcinoma has been reported $[17,18,26]$. In a study conducted by Askling et al. [30] a population cohort with 11,019 celiac individuals was used. The incidence analysis in this cohort showed a 2.3fold increased risk of celiac disease developing oropharyngeal cancer and a 4.2-fold increased risk of oesophagal cancer [30]. However, these results have not yet been replicated in American countries.

\section{Conclusion}

Due to the immunogenic characteristic of the celiac disease and the persistence of not implementing a strict gluten-free diet, patients are increasingly likely to develop a range of malignancies whose survival time is sometimes unsatisfactory. Reports of previous studies by several authors show the prevalence of neoplasias and their complications. These studies reinforce the high degree of dangerousness of celiac patients, as well as the need for a rigorous dietary implementation and the development of new treatment approaches.

\section{Competing Interests}

None of the authors has any competing interests.

All authors contributed equally to this work.

\section{Reference}

1. Halina Mayer Chaves Araújo, Wilma Maria Coelho Araújo, Raquel Braz Assunção Botelho, Renata Puppin Zandonadi (2010) Doença celíaca, hábitos e práticas alimentares e qualidade de vida. Rev Nutr 23(3): 467-474.

2. Green PH, Cellier C (2007) Celiac Disease. N Engl J Med 357(17): 17311743.

3. Taufner GH, Destefani AC (2017) Finding and Updates in Celiac Disease. EC Gastroenterol Dig Syst 1: 192-199.

4. Casellas F, Rodrigo L, Vivancos JL, Riestra S, Pantiga C, et al. (2008) Factors that impact health-related quality of life in adults with celiac disease: a multicenter study. World J Gastroenterol 14(1): 46-52.

5. Hill ID, Dirks MH, Liptak GS, Colletti RB, Fasano A, et al. (2005) Guideline for the diagnosis and treatment of celiac disease in children: recommendations of the North American Society for Pediatric Gastroenterology, Hepatology and Nutrition. J Pediatr Gastroenterol Nutr 40(1): 1-19.

6. Mustalahti K, Catassi C, Reunanen A, Fabiani E, Heier M, et al. (2010) The prevalence of celiac disease in Europe: Results of a centralized, international mass screening project. Ann Med 42(8): 587-595.

7. Rubio-Tapia A, Kyle RA, Kaplan EL, Johnson DR, Page W, et al. (2009) Increased Prevalence and Mortality in Undiagnosed Celiac Disease. Gastroenterology 137(1): 88-93.

8. Ludvigsson JF, Montgomery SM, Ekbom A, Brandt L, Granath F (2009) Small-Intestinal Histopathology and Mortality Risk in Celiac Disease. JAMA 302(11): 1171-1178.

9. Metzger $\mathrm{MH}$, Heier $\mathrm{M}$, Mäki M, Bravi E, Schneider A, et al (2006) Mortality Excess in Individuals with Elevated IgA AntiTransglutaminase Antibodies: The KORA/MONICA Augsburg Cohort Study 1989-1998. Eur J Epidemiol 21(5): 359-365.

10. Peters U, Askling J, Gridley G, Ekbom A, Linet M (2003) Causes of Death in Patients With Celiac Disease in a Population-Based Swedish Cohort. Arch Intern Med 163(13): 1566-1572.

11. Brousse N, Meijer JW (2005) Malignant complications of coeliac disease. Best Pract Res Clin Gastroenterol 19(3): 401-412.

12. Catassi C, Bearzi I, Holmes GK (2005) Association of celiac disease and intestinal lymphomas and other cancers. Gastroenterology 128(4-1): S79-S86.

13. Moscoso J F, Quera PR (2016) Enfermedad celíaca. revisión. Rev Med Chil 144(2): 211-221.

14. West J, Logan RF, Smith CJ, Hubbard RB, Card TR (2004) Malignancy and mortality in people with coeliac disease: population based cohort study. BMJ 329(7468): 716-719.

15. Green PH, Fleischauer AT, Bhagat G, Goyal R, Jabri B, et al. (2003) Risk of malignancy in patients with celiac disease. Am J Med 115(3): 191195.

16. Howdle PD, Jalal PK, Holmes GK, Houlston RS (2003) Primary smallbowel malignancy in the UK and its association with coeliac disease. QJM 96(5): 345-353. 


\section{Cancer Therapy \& Oncology International Journal}

17. Holmes GK, PL Stokes, TM Sorahan, P Prior, JA Waterhouse, et al. (1976) Coeliac disease, gluten-free diet, and malignancy. Gut 17(8): 612-619.

18. Selby WS, Gallagher ND (1979) Malignancy in a 19-year experience of adult celiac disease. Dig Dis Sci 24(9): 684-688.

19. Harris OD, Cooke WT, Thompson H, Waterhouse JA (1967) Malignancy in adult coeliac disease and idiopathic steatorrhoea. Am J Med 42(6): 899-912.

20. Leslie LA, Lebwohl B, Neugut AI, Gregory Mears J, Bhagat G, et al (2012) Incidence of lymphoproliferative disorders in patients with celiac disease. Am J Hematol 87(8): 754-759.

21. Corrao G, Corazza GR, Bagnardi V, Brusco G, Ciacci C, et al. (2001) Mortality in patients with coeliac disease and their relatives: a cohort study. Lancet (London, England) 358(9279): 356-361.

22. Catassi C, Fabiani E, Corrao G, Barbato M, De Renzo A, et al. (2002) Risk of Non-Hodgkin Lymphoma in Celiac Disease. JAMA 287(11): 14131419.

23. Freeman HJ (1996) Neoplastic disorders in 100 patients with adult celiac disease. Can J Gastroenterol 10(3): 163-166.
24. Freeman HJ (1994) Occult celiac disease in an octogenarian presenting with a small intestinal adenocarcinoma. Can J Gastroenterol 8(6): 354357.

25. Neugut AI, Marvin MR, Chabot JA (2001) Adenocarcinoma of the small bowel.

26. Freeman HJ (2009) Malignancy in adult celiac disease. World J Gastroenterol 15(3): 1581-1583.

27. Buaisha H, Nippoldt E, Alsuwaidan AN, Reddymasu S (2016) Small Bowel Adenocarcinoma in Celiac Disease: a Case Report. J Gastrointest Cancer.

28. Catassi C, Bearzi I, Holmes GK (2005) Association of celiac disease and intestinal lymphomas and other cancers. Gastroenterology 128(4S): 79-86.

29. Logan RF, Rifkind EA, Turner ID, Ferguson A (1989) Mortality in celiac disease. Gastroenterology 97(2): 265-271.

30. Askling J, Linet M, Gridley G, Halstensen TS, Ekström K, et al. (2002) Cancer incidence in a population-based cohort of individuals hospitalized with celiac disease or dermatitis herpetiformis. Gastroenterology 123(5): 1428-1435.

\section{Your next submission with Juniper Publishers} will reach you the below assets

- Quality Editorial service

- Swift Peer Review

- Reprints availability

- E-prints Service

- Manuscript Podcast for convenient understanding

- Global attainment for your research

- Manuscript accessibility in different formats

( Pdf, E-pub, Full Text, Audio)

- Unceasing customer service

Track the below URL for one-step submission https://juniperpublishers.com/online-submission.php 